\title{
Justice Could Be Highlighted in the Perspective of Historical Materialism*
}

\author{
Guowang Xu, Wei Zheng \\ Marxist Philosophy, College of Philosophy, Value and Cultural Center, Beijing Normal University, Beijing, China \\ Email: xuguowang_0001@163.com
}

Received 15 April 2016; accepted 27 June 2016; published 30 June 2016

Copyright (C) 2016 by authors and Scientific Research Publishing Inc.

This work is licensed under the Creative Commons Attribution International License (CC BY). http://creativecommons.org/licenses/by/4.0/

(c) (i) Open Access

\begin{abstract}
How to understand the relationship between historical materialism and Marx's idea of justice? The well-know Canadian philosopher, Kai Nielsen, "who is indeed closer to Marxist moralism in substantive conclusion, but, methodologically speaking, it is more in the spirit of Marxist immoralism" (Nielsen,1987: p. 114), points out Marx's ideological system is not a valueless theory of science and society, and the facts and value judgments can be unified in Marx's theory. Nielsen reveals the profound idea of justice as the basic dimension of historical materialism, and the internal unity of fact judgment and value judgment in a dual dimensions, based on the perspective of historical materialism, showing "justice could be highlighted in the perspective of historical materialism".
\end{abstract}

\section{Keywords}

Historical Materialism, Marx's Idea of Justice, Fact Judgment, Value Judgment

\section{The Theoretical Background: Marxist Moralism and Marxist Immoralism}

In the fierce debate of analyzing Marxists, two opposite tendencies were formed: Marxist moral theory and Marxist anti-moral theory. The former holds the view that "The historical materialism rejects and eliminates the idea of justice", but the latter is behind the point that "Justice transcends and eliminates historical materialism". The well-know Canadian philosopher, Kai Nielsen, who "is indeed closer to Marxist moralism in substantive conclusion, but, methodologically speaking, it is more in the spirit of Marxist immoralism...” (Nielsen, 1987: p. 114), studies the relationship between Marx's idea of justice and historical materialism with hierarchical dialectics, context theory, class analysis and other ways, based on the perspective of historical materialism. Nielsen affirms the scientificity of historical materialism facts, in the meantime, he also points out Marx's ideological system is not a valueless theory of science and society, and the facts and value judgments can be unified in

*The Experience and Constellation: The Study of Adorno’s “Negative Dialectics”, 15FKS004. 
Marx's theory. This reveals the profound idea of justice as the basic dimension of historical materialism, and the internal unity of fact judgment and value judgment in dual dimensions, showing "justice could be highlighted in the perspective of historical materialism". Definitely, the study about "the relationship between historical materialism and the idea of justice" by Nielsen, provides a new path for resolving this problem.

The two Nielsen's mentioned concepts, namely historical materialism and idea of justice, mainly originate from Marx, within which the latter will be extensively involved in the following contents, not required an immediate interpretation here. In another way, Marx's classic illustration on historical materialism is embodied notably in the Preface to the Critique of Political Economy:

"The totality of these relations of production constitutes the economic structure of society, the real foundation, on which arises a legal and political superstructure and to which correspond definite forms of social consciousness. The mode of production of material life conditions the general process of social, political and intellectual life. It is not the consciousness of men that determines their existence, but their social existence that determines their consciousness... The changes in the economic foundation lead sooner or later to the transformation of the whole immense superstructure. In studying such transformations it is always necessary to distinguish between the material transformation of the economic conditions of production, which can be determined with the precision of natural science, and the legal, political, religious, artistic or philosophic - in short, ideological forms in which men become conscious of this conflict and fight it out.” (Marx et al., 1995: p. 32).

Marx developed a scientific elaboration about the dialectic relationship between the productive forces and productive relationship, as long with base and superstructure, which represents a typical generalization on elements of historical materialism.

\section{Historical Materialism Is the Premise for Using the Idea of Justice}

From a pure and abstract moral view to discuss the issue of justice, Nielsen claims that historical materialism is the premise and the objective criterion for using the idea of justice which is the basic dimension of historical materialism as the moral category, against Marxist scholars of morality who Ignores the limitation of production methods, class interests and other objective facts in the context of historical materialism. Nielsen believes that the interaction between the productive forces and the productive relations reveals the historical objectivity of the human society, and claims to understand the moral and justice from historical connection, the development mode of production, the "social-objective-environmental" changes in the contextualism, against the eternal moral principle and the "Archimedean point" of meta ethics. We cannot educe "is" from "should", but in the process of moral reasoning we still continue to support our moral judgment by appealing to the facts (Nielsen, 1979). That is same to Marx's strong moral criticism to the alienation of labor: "Starting from the economic facts which belong to the capitalist private ownership" (Xu \& Zheng, 2015). Nielsen goes on to say "We do, in fact, should, base the moral judgment on the facts. No matter what autonomic views of ethics we have, we must be aware of the facts that the value judgments which occur repeatedly in our daily life are based on the facts." (Nielsen, 1989). That is to say, Nielsen rejects the dualism of "facts and value". Not only does he support the autonomy of morality and justice, but also points out moral judgment is the fact judgment of historical materialism, which is accorded with "claims which have a moral force but are still claims which have empirical truth-conditions and are part of an empirical social science” (Nielsen, 1986: p. 33).

Nielsen believes that "to eliminate the class itself" is the pre-condition and foundation of completely social justice. He points out "only when the class society is completely overcame", can the surface and actual inequality in politics, law, society and economy be eliminated, according to Marx's view that "all the political and social inequality caused by the class differences would perish with the elimination of those differences" (Marx et al., 2009: p. 442). Nielsen disagrees anti-moralism to put the class interests against morality and justice, and he claims the idea of justice is "the essential part of Marx's overall social theory, which accords with his theory of revolutionary struggle greatly" (Nielsen, 1989: p. 62). It does not mean that we have to try everything to avoid evaluating socialism or capitalism with the idea of justice, if we insist on the theory of class interests. We can morally and justly criticize capitalism based on the theory of class interests and the revolutionary practice (Nielsen, 1988: pp. 212-234). Nielsen goes deep into capitalist economic structure and class structure to explore the roots which have influences on actual equality with class analysis of historical materialism: class differentiation (Yu, 2013: pp. 48-54), breaking through the narrow field of capitalist political liberation.

Nielsen analyzes the content of Critique of the Gotha Programme and Captial in his book named Marxism 
and the Moral Point of View, and then thinks that the premise of Marx's judgment for justice is the material conditions and economic organizations of social life in the special historical contextualism. Nielsen expresses his view that "what we would correctly judge to be just or unjust at a given time is fixed by the level of development of economic relations at that time" (Nielsen, 1986: p. 25), with a classic sentence of Marx that "Doesn’t the bourgeois assert today's distribution is fair? Isn't it, in fact, the only 'fair' allocation that is based on the current production method?” (Marx et al., 2009: p. 432). This view is of course not a "relativism but a contextualism which is perfectly compatible with a belief in moral objectivity" (Nielsen, 1986: p. 33). The contextualism we talked above is: The concrete and distinct principles of justice that we have is "uniquely applicable to that society with that mode of production" (Nielsen, 1989: p. 737), and there will never be a principle of justice that is applicable to all historical environments.

\section{Justice Implies the Inner Unity of Fact Judgment and Value Judgment in the Dual Dimension}

Nielsen is against the people of Marxist moralism who only talk about issues of justice from the perspective of history and economic determinism but ignoring the kinetic energy and value of morality. He claims "Justice itself implies the inner unity of fact judgment and value judgment in the dual dimension", and the dimension of moral value judgment, as a basic dimension of historical materialism, can be the extension based on the fact judgments. Nielsen thinks "Marx (pace Wood) was concerned in The Critique of the Gotha Programme with the justice and, more generally, with the moral adequacy, of different distributive schemes that go with different modes of production" (Nielsen, 1988: p. 319). Historical materialism demonstrated "even if the historical materialism was a reliable view of epoch-making changes related to the society, it did not collapse the faith of moral objectivity” (Nielsen, 1989). In the perspective of historical materialism, the particular moral belief, idea of justice, adapt to the mode of production relatively, in the meantime, historical materialism also make a commitment clearly to the contextualism, not rejecting the moral progress, and a commitment to a kind of progress of moral belief. The adaptation of the idea of justice and the mode of production here are mainly presented as the dimension of fact judgment, and its progress is the dimension of moral value judgment.

Nielsen points out clearly, from some daily comments like "slave", "theft" in the Critique of the Gotha Programme, or from the comments that Marx critiques that "moral discourse about the power and fair distribution of LaSalle School is a crime", it can be seen that Marx has clearly demonstrated his moral value judgment confidently. As for the phrase "social scourge" which is used in the text that "Enable the workers to and have to eradicate the social scourges", Nielsen points out it makes us "master a normative phrase with obvious emotional cues and full power again". If Marx's empirical social analysis is right, the phrase like "slave" and "social curse" will not become "completely emotional or biased", on the contrary, "They are both morally appropriate and empirically apt for the characterization of the situation” (Nielsen, 1986: p. 25). Nielsen thinks that this kind of normative phrases also shows the inner unity of fact judgment and value judgment in the dual dimension.

Marx certainly regarded capitalism as a system of slavery, and vehemently condemn the injustice which was lied in the work hours of workers in capitalist society. This kind of criticism is not only a kind of factual criticism, but also a strong moral value judgment. The work hours "not only broke through the moral limit of the weekdays, but also broke through the limit of the pure physical body on weekdays. It occupied the time for the growth, development and health of humans' bodies" (Marx et al., 2004: p. 306). In the factual level, capitalist society exploits workers' surplus value and uses this surplus value to a new exploitation. In the moral-value level, it makes the workers live a slave-life under the repression of a one-way development, without the dignity and freedom which should belong to "people". Of course, when Marx affirmed that in capitalism the workers life was like the slavery or worse, he was regarding the social conditions but economically. Marx recognized that the economic situation in capitalism presupposed economic freedom to choose for whom to sell his labor-force. This is clearly beyond the factual inequality. Marx shows the defects of capitalism in the dual dimensions of objective facts and moral values, which further to makes Nielsen firmly believe that Marx's idea of justice has "the empirical facts and the obviously moral strength” (Nielsen, 1989: p. 62).

\section{The Relationship between Justice and Historical Materialism Is Dialectical Interaction}

Nielsen comes up with the view that the relationship between justice and historical materialism is "dialectical 
interaction and reciprocal causation”, based on Marx’s deep recognition of historical materialism and survey of two opposite perspectives which are moralism and amorialism. Nielsen thinks: "Marx, as a historical materialist, would deny that economic relations are ruled by juridical one, but would also realize that bases need superstructures, that juridical relations can and do influence economic relations, and that, though economic relations are primary, there is a dialectical category of reciprocal action (Wechselwirkung) or bilateral causation between base and superstructure” (Nielsen, 1988: p. 57). Therefore, we have no reason to believe that Marx would think that justice is useless. Nielsen thinks the fact judgment of the idea of justice is consistent with the factually-scientific judgment of historical materialism. The value judgment of the idea of justice is based on "Marx's historical and social analysis which is the empirical theory of the relationship between economic base and superstructure". That is to say, the value judgment of the idea of justice is the further recognition based on the premise of the factually-scientific judgment of historical materialism. The same as what Nielsen said, "If that analysis and that theory are approximately true, then Marx’s moral evaluations follow rather trivially.” (Nielsen, 1986: p. 30).

Nielsen thinks the historical materialism is that "the described 'to be' of historical facts, empirical facts, economic facts spontaneously correspond with the 'ought to be' of the moral value judgment” (Yu, 2013: pp. 48-54). Justice, as the basic dimension of historical materialism, makes the factually-scientific judgment and value judgment unified in the perspective of historical materialism, and also forms the relationship which is "dialectical interaction and reciprocal causation”, between historical materialism and the idea of justice.

Nielsen reveals the profound idea of justice, as the basic dimension of historical materialism, and the internal unity of fact judgment and value judgment in dual dimensions, showing justice could be highlighted in the perspective of historical materialism, with hierarchical dialectics, context theory, class analysis and other ways. Not only does Nielsen's theory transcend Marxist amorlism's view that "the historical materialism rejects and eliminates the idea of justice”, but also sublates Marxist moralism's view that "Justice transcends and eliminates historical materialism”, achieving the unity of Marx’s idea of justice and historical materialism. Undoubtedly, it provides a new perspective for the problem about the elimination and reconstitution of the relationship between "historical materialism and the idea of justice", and it is a new try for the path about the further study of the factually-scientific and morally-valuable dimension of Marx’s theory. Of course, in Nielsen's study about the relationship between "historical materialism and the idea of justice”, there still are some theoretical problems needing further discussions. For instance, is the value judgment which belongs to Marx's idea of justice the basic dimension of historical materialism? Does Marx's idea of justice have some contents independent from the perspective of historical materialism? The thought and study about this problem may make us have a further recognition about the intrinsic tension of the relationship between "historical materialism and the idea of justice", or may provide a new path for the development and abundance of Marx’s theory.

\section{References}

Marx et al. (1995). Marx and Engels Anthology. Vol. 2, People’s Publishing House.

Marx et al. (2004). Marx and Engels Anthology. Vol. 5, People’s Publishing House.

Marx et al. (2009). Marx and Engels Anthology. Vol. 3, People’s Publishing House.

Nielsen, K. (1979). On Deriving an Ought from an Is: A Retrospective Look. The Review of Metaphysics, 32.

Nielsen, K. (1986). Marx, Engels and Lenin on Justice: The Critique of the Gotha Programme. Studies in Soviet Thought, 32, 33.

Nielsen, K. (1987). Justice, Class Interests and Marxism. Philosophica, 39, 114.

Nielsen, K. (1988). Arguing about Justice: Marxist Immoralism and Marxist Moralism. Philosophy and Public Affairs, 17, 212-234.

Nielsen, K. (1988). Marx on Justice: The Tucker-Wood Thesis Revisited. The University of Toronto Law Journal, $38,57$.

Nielsen, K. (1988). On Marx Not Being an Egalitarian. Studies in Soviet Thought, 35, 319.

Nielsen, K. (1989). Marxism and Arguing for Justice. Social Research, 56, 737.

Nielsen, K. (1989). Marxism and the Moral Point of View: Morality, Ideology and Historical Materialism. Westview Press.

Xu, G. W., \& Zheng, W. (2015). Practical Significance of Marx's Theory of Alienation Based on the "Economic and Philosophical Manuscripts of 1844” Perspective. Gansu Theory Research, 6, 95.

Yu, J. H. (2013). Historical Materialism, Morality, Justice, and Evaluation of Marxist Immoralism and Marxist Moralism. Marxism \& Reality, 5, 48-54. 


\section{Submit or recommend next manuscript to SCIRP and we will provide best service for you:}

Accepting pre-submission inquiries through Email, Facebook, Linkedin, Twitter, etc A wide selection of journals (inclusive of 9 subjects, more than 200 journals)

Providing a 24-hour high-quality service

User-friendly online submission system

Fair and swift peer-review system

Efficient typesetting and proofreading procedure

Display of the result of downloads and visits, as well as the number of cited articles

Maximum dissemination of your research work

Submit your manuscript at: http://papersubmission.scirp.org/ 